\title{
The Corporate Governance of Human Resource Outsourcing at the State-Owned Bank In Makassar
}

\author{
Hardiani \\ Fakhri Kahar \\ Hery Tahir \\ Department of Public Administration, Universitas Negeri Makassar, Jl. Bonto Langkasa, Kampus Gunung Sari Baru \\ Postal Code 90222; hardianialiyusuf@yahoo.co.id, f.kahar@yahoo.com, profheritahir@yahoo.com
}

\section{Doi:10.5901/mjss.2016.v7n2s1p284}

\section{Abstract}

This research aims at examining and analysing the application of the good corporate governance principles in cooperation between the state-owned bank and the provider of human resources outsourcing. The special target in this research is finding out application model of the good corporate governance principles in cooperation between the state-owned bank and the provider of human resources outsourcing. This research was a descriptive qualitative method. The data were analysed using interactive analysis model. This research was conducted in the state-owned bank in Makassar that employed human resources outsourcing. Therefore, this research was conducted in Mandiri Bank Makassar and provider of human resources outsourcing. The results show that the application of the good corporate governance principles in cooperation between the state-owned bank and the provider of human resources outsourcing has been conducted actively. Therefore, it can be recommended model in terms of the application of the principles of corporate governance of the state-owned bank.

Keywords: transparency, accountability, responsibility, independence, fairness

\section{Introduction}

Human resource is one of the primary capital for the success of a company. The whole of the factors of production owned by the company will not produce anything without the role of human resources. Various attempts are made to obtain reliable human resources with the appropriate and expected skills.

Moreover, the scope of work is increasingly widespread, and the current globalization is increasingly intense. Therefore, the development of technology and changes in consumer behaviour have created an increasingly tight competition in the business world.

A company can no longer rely on conventional or traditional ways of running a business in order to survive and win the competition. The company must continue to seek new ways and design a right strategy to adjust its business processes with the increasingly rigorous competition environment.

In this kind of business environment, a company is not able to run his own business activities without working with other companies. A company's efforts that emphasize cooperation with other companies and highly relevant to the current business environment conditions is the utilization of outsourcing.

Outsourcing is the submission of a particular job from a company to another party. It is conducted to share the risk and reduce the burden on the company. This business venture is mutually beneficial to the parties. The intended parties are the company as the giver of a contractor job, the company as the receiver, and workers. Either the companies or the outsourced workers have been regulated by the Act No. 13 in 2003 on Labour. It is in line with the principles of good corporate governance, namely transparency, accountability, responsibility, independence and fairness.

For banks, the application of the principles of Good Corporate Governance (GCG) is one of the absolute prerequisites in the process of transformation. The good application of the principles will boost investor confidence and provide added value for shareholders and other stakeholders. It is written PBI No. 8/4/PBI/2006 on 30 January 2006 and PBI No. 8/14/PBI/2006 on 05 October 2006 regarding changes to PBI No. 8/4/PBI/2006 as well as SE BI No. 9/12/DPNP on 30 May 2007 on the implementation of Good Corporate Governance for commercial banks.

Based on the above background, the writers are interested in conducting further research at the state-owned bank in Makassar especially at Mandiri Bank Makassar with the company as the provider of human resources outsourcing. 


\subsection{Research formulation}

Based on the description of the conditions and problems of corporate governance of human resource outsourcing, the basic issue that is examined is the extent to which the application of the principles of good corporate governance in cooperation between the state-owned bank and the provider of HR outsourcing.

\section{Review of Related Literature}

\subsection{The state-owned bank}

According to the Law No. 7 in 1992 about Banking as amended by the Law No. 10 of 1998, the Bank is a business entity which collects funds from the public in the form of deposits, and distributes them to the public in order to improve the standard of living of the society.

According to ownership, banks in Indonesia are divided into three types:

a. The state-owned bank means that the government possesses some or all of the shares. The regional development bank is also included in this category because it is owned by the local government for example Jatim Bank, Jabar Bank, and others.

b. The private-owned bank is the bank that all shares are owned by private parties.

c. The cooperative-owned bank is a bank that all shares are owned by cooperatives, for example, BUKOPIN Bank.

\subsection{Outsourcing Agent}

Outsourcing comes from the word "out" which means go out and "source" which means resources. In practice, the basic definition of outsourcing is the transfer of part or all of the work and authority to other parties in order to support the strategy of outsourcing service users either personal, company, division or a unit within a company.

Outsourcing contracts can be defined as a form of contract between the company as job giver and worker provider to be employed in a certain period of time in accordance with the contract that had been agreed upon by both parties. Therefore, in this case, the company as a user of the workforce do not have a relationship with the workers who are employed directly because the workers are through the company outsourcing agency.

According to Komang and Agus (2008) the outsourcing type are distinguished into two groups namely:

1. Business Process Outsourcing (BPO) in Indonesia is known as a chartering job. This kind of outsourcing refers to the desired result. If a manufacturing company wants to turn its product sales to other companies, the payment of the compensations is in the form of the number of the sold units.

2. Human Resource Outsourcing (HRO) refers to the needs of the provision and management of human resources. The company will be working with outsourcing companies (vendors) that provide services in the provision and management of labour. Compensation to vendors is a management fee according to the agreement.

Outsourcing is a form of agreement between the company $A$ as service user and company $B$ as provider, where company $\mathrm{A}$ asks for company $\mathrm{B}$ to provide the necessary labour to work in company $\mathrm{A}$ by paying some retributions or wages to company $B$ based on agreement.

The developments in subsequent years showed that the company's organization grew complex. Its resources also go hand in hand that are more into specialization which is fixed on various elements of the company's operations for example product design, engineering, manufacturing, human resources, information technology, logistic, and sales.

This research is expected to obtain information about the company in an effort to minimize the negative impact of the utilization of outsourcing, namely:

\subsubsection{For company}

1. There is a complexity of working relationships in terms of giving work orders, warnings and sanctions because the employers are not the entrepreneur.

2. There is a change of the status of the working relation from the fixed labour to the unfixed labour. 


\subsubsection{For labour}

1. There is job dissatisfaction because the company can terminate employment at any time without any prior information.

2. There is a decrease in the level of welfare because the company as the job giver pays compensation to the provider of workers. Meanwhile, the workers are paid by the worker provider. Therefore, the wage is not entirely accepted by the workers; even it is cut up to $30 \%$.

3. There is an unclear career level. Therefore, it raises insecurity in working.

The outsourcing agent is a company engaged in the field of labour providers. A previous study entitled "Outsourcing Human Resources: an Overview from the Perspective of the Vendor and Employee" which was written by Salamah Wahyuni (Universitas Sebelas Maret) and M.S. Djumilah Idrus, Zain, and Mintarti Rahayu (Universitas Brawijaya) outlined that outsourcing mainly to human resources is something that is relatively new in Indonesia. It began to develop around the end of the nineties, and it developed rapidly after 2000. Since 2002, there are many companies that use outsourcing strategies in the provision and management of its human resources. Therefore, outsourcing companies as vendors that provide services for the provision and management of labour services are also growing fast. It indicates that the outsourcing company is a business that has a promising prospect for the outsourcing agent. With its experience and information, the outsourcing agent can build strength that may be difficult to control the company. Therefore, the company must actually believe that its partner will not be a renegade.

\subsection{Agency Theory}

In the agency theory, agency relationship arises when one or more people (principal) employs another person (agent) to provide a service, and then they delegate the decision-making authority to the agent. Jensen and Meckling (1976) in Masdupi (2005, p. 59) defines the agency theory as the relationship between the agent (management of a business) and principal (business owners). In the agency relationship, there is a contract in which one or more persons (principal) control another person (the agent) to perform a service on behalf of the principal. In addition, the principal authorize the agent to make decisions that are best for the principal.

In the agency relationship, the agent is expected to take decision especially the decision that leads to things that benefit the owner of the company. When management decision is adverse to the owner of the company, agency problems will arise (Hanafi and Ismiyanti, 2004, p. 176).

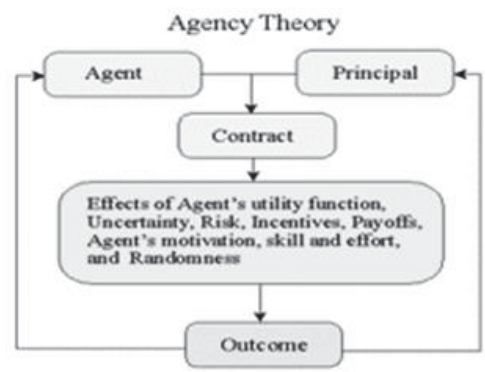

Source: Ismiyanti dan Hanafi, 2004, p. 180

One of the most effective ways to use as a tool of control that restrict the deviant behavior is the application of the principles of good corporate governance.

\subsubsection{The Concept of Corporate Governance.}

Corporate governance arises due to the separation between ownership and control of the company. The corporate governance is a system built to direct and control the company. Therefore, it can create a good, fair, and transparent relationship among the concerned parties such as stakeholders.

The regulation of the Minister of State-owned Enterprises number 01/MBU/2011 about the implementation of good 
corporate governance in State-owned enterprises, has outlined the principles of good corporate governance in chapter II of part 1 of article 3. The principles of good corporate governance consist of:

1. Transparency is openness in the decision-making process and openness in disclosing the relevant information about the company;

2. Accountability is a function of clarity about the implementation of organs so that the management of the company will operate effectively;

3. responsibility is the conformity of legislation and the principles of a healthy corporation in managing the company;

4. Independency is a condition in which the company is managed professionally without conflicts of interest and pressure from any party that is not in agreement with the legislation and the principles of a healthy corporation;

5. Fairness is justice and equality in fulfilling the rights of stakeholders that arise based on agreement and legislation.

\section{Method}

This research was a descriptive qualitative research. This research used a case study approach. The research location was in Mandiri Bank of Makassar that includes 37 work units. It consists of 3 branches, 28 sub-branches or KCP and six cash offices or KK. They spread not only in the city of Makassar but also in several districts and islands along with its partner of the company that became the provider of human resources outsourcing.

\section{THE TOTAL OF WORK UNIT \& STAFF}

MANDIRI BANK OF MAKASSAR AREA

\begin{tabular}{|c|l|c|}
\hline No & WORK UNIT & STAFF \\
\hline 1 & KC Ambon Pantai Mardika & 41 \\
\hline 2 & KC Ambon Pattimura & 39 \\
\hline 3 & KC Makassar Kartini & 112 \\
\hline 4 & KCP AMBON MASOHI & 4 \\
\hline 5 & KCP AMBON NAMLEA & 8 \\
\hline 6 & KCP AMBON PARADISO & 6 \\
\hline 7 & KCP AMBON PASO & 4 \\
\hline 8 & KCP AMBON TUAL & 3 \\
\hline 9 & KCP BULA & 3 \\
\hline 10 & KCP Gemba & 3 \\
\hline 11 & KCP MAKASAR PERINTIS KEMERDEKA & 4 \\
\hline 12 & KCP MAKASAR PUSAT GROSIR DAYA & 5 \\
\hline 13 & KCP MAKASSAR ANDALAS & 12 \\
\hline 14 & KCP Makassar BTP & 4 \\
\hline 15 & KCP Makassar Cokroaminoto & 20 \\
\hline 16 & KCP MAKASSAR DAYA & 13 \\
\hline 17 & KCP MakasSar Kima & 2 \\
\hline 18 & KCP MAKASSAR MAROS & 5 \\
\hline 19 & KCP Makassar Paccerakkang & 2 \\
\hline 20 & KCP MAKASSAR PANNAMPU & 4 \\
\hline 21 & KCP MAKASSAR PASAR TERONG & 4 \\
\hline 22 & KCP MakasSar Slamet Riyadi & 27 \\
\hline 23 & KCP MAKASSAR SUDIANG & 6 \\
\hline 24 & KCP MakasSar Sulawesi & 15 \\
\hline 25 & KCP MAKASSAR VETERAN & 11 \\
\hline 26 & KCP MaroS Camba & 2 \\
\hline 27 & KCP Maros Sudirman & 5 \\
\hline 28 & KCP PANGKEP HASANUDIN & 4 \\
\hline 29 & KCP PANKAJENE & 6 \\
\hline 30 & KCP SEMEN TONASA & 4 \\
\hline 31 & KCP TUAL & 9 \\
\hline & & \\
\hline & & 2 \\
\hline
\end{tabular}




\begin{tabular}{|c|l|c|}
\hline 32 & KK AMBON UNIVERSITAS PATTIMURA & 4 \\
\hline 33 & KK MAKASAR PASAR SENTRAL & 7 \\
\hline 34 & KK MAKASAR SOMBA OPU & 7 \\
\hline 35 & KK Makassar Pelabuhan Indonesi & 4 \\
\hline 36 & KK Makassar Stela Maris & 4 \\
\hline 37 & KK Makassar Univ Hasanuddin & 4 \\
\hline TOTAL & & 417 \\
\hline
\end{tabular}

Source: Mandiri Bank, 2015

\section{Results and Discussion}

The role of the principles of good corporate governance of state-owned bank on human resources outsourcing is urgently needed as a governing tool. Therefore, system and procedures that take place are in accordance with the corridor that has been established by the company. The research focuses on the application of the principles of good corporate governance especially for recruitment mechanisms, training and the granting of compensation for outsourcing.

Based on the results of this research, it is found that the company has applied the application of good corporate governance principles namely transparency, accountability, corporate responsibility, independence and fairness. Thus, the principles of good corporate governance have been become the foundation of any operating rules and policies of the company. It is similar in establishing mechanisms and procedures that become the terms and conditions of cooperation between Mandiri Bank (the state-owned bank in Makassar) as the user and the company as the provider of human resources outsourcing. As the user of outsourcing, the state-owned bank is very strict in applying the terms and conditions that must be adhered to by the vendor as the provider of human resources outsourcing. The selection system in the process of recruitment, training and the granting of compensation to the outsourcing must comply with the predetermined requirements.

If the vendor makes a mistake or omission that deviates from the agreement, it will be sanctioned in the form of a warning letter. If it is not concerned with the warning, the company will not continue co-operation after the cooperation period ends.

In order to awake the governance that has been established, the company took over the reins to overcome irregularities or negligence committed by the vendor.

Mandiri Bank continues to maintain consistency in applying the principles of good corporate governance (GCG) in every business process. One of the results is a recognition of the Journal Corporate Asian (CGA) as the best icon of GCG implementation in the country.

CGA Annual Recognition Award 2013 (Best of Asia) for the category of Asia's Icon on Corporate Governance is submitted by CGA Publisher namely Aldrin Monsod to the Director of Compliance and Human Capital of Mandiri Bank (Ogi Prastomiyono) in Manila, Philippines, on Tuesday night (25/6/2013). The Best of Asia award was the fifth award of Mandiri Bank.

A comprehensive application of the principles of GCG become an important factor that determines the level of profitability and reputation of a company. It is also a success in providing added value to stakeholders through several ways:

1. Enforcing a code of conduct and business ethics as guidelines to behave for the whole range of Mandiri Bank in terms of the internal and external relationship, such as stockholders, affiliates, investors, customers, suppliers, governments and communities.

2. Obligating the entire employees to fill out and sign an annual disclosure.

Through the implementation of good corporate governance, the entire human resources in Mandiri Bank are tying themselves to implement the code of conduct, oath of office, and other applicable regulations. Therefore, the recommended model in the application of the principles of good corporate governance in cooperation between the sateowned bank and the provider of HR outsourcing is the model that has already applied to Mandiri Bank.

\section{Conclusion}

The company has applied the application of governance principles namely transparency, accountability, responsibility, independence and fairness. The comprehensive application of good corporate governance becomes an important factor that determines the level of profitability and reputation of a company as well as its success in providing added value to 
stakeholders. Through the implementation of good corporate governance, the entire human resources in Mandiri Bank are tying themselves to implement the code of conduct, oath of office, and other applicable regulations. Based on the above results, the recommended model in the application of the principles of good corporate governance in cooperation between the sate-owned bank and the provider of HR outsourcing is the model that has already applied to Mandiri Bank.

\section{References}

Alwi, Syarifuddin. (2001). Human Resources Management Financial Strategy Competitive. Yogyakarta: BPFE.

Ardana, I Komang, et al. (2012). Human Resources Management. Yogyakarta: Graha IImu.

Arief, Idris, M. (2001). Human Resources Management. Makassar: Bahan Kuliah PPS-STIEM.

Bank of Mandiri. (2013). Charter Risk Monitoring Committee \& Good Corporate Governance (GCG). Jakarta.

Circular Letter of Bank of Indonesia No.9/12/DPNP on 30 May 2007 about the Application Good Corporate Governance for Regular Bank.

Damanik, Sehat. (2006). Outsourcing and According to the Employment Agreement Law No. 13, 2003 about Employment. Jakarta: DSS Publishing.

Depdiknas. (2008). Processing and Data Analysis Research. Jakarta: Departemen Pendidkan Nasional.

Ismiyanti, Fitri., \& Hanafi, Mamduh M. (2004). Ownership Structure, Risk and Financial Policy Analysis Simultaneous Equation. Jurnal Ekonomi dan Bisnis Indonesia, Vol. 19 (2), pp. 176 -196.

Law No. 7, 1992 modified Law No. 10, 1998, about Banking.

Law No. 3, 1992 about Guarantee of Social Security.

Law No.13, 2003 about Employment.

Law No. 13, 2003 article 58 about Probation on PKWT.

Law No. 13, 2003 article 59 about contract on PKWT.

Law No. 13, 2003 article 60 about Probation on PKWT.

Law No. 13, 2003 article 62 about Severance.

Law No. 13, 2003 article 65 about Work Chartering Agreements.

Law No. 13, 2003 article 66 about supporting activities of the Company and Disputes Settlement.

Masdupi, Erni. (2005). Ownership Structure Impact Analysis on Debt Policy to Controlling Conflict Agency. Jurnal Ekonomi dan Bisnis, Vol 2 (1), pp. 57-69.

Masdupi, Erni. (2005). Agency Theory.

News Release. (2013). Bank of Mandiri becomes the Best Icon as GCG Application. On Tuesday, 25 June 2013. Jakarta.

Priambada, Komang., \& Maharta, Agus Eka. (2008). Outsourcing versus Employee. Jakarta: Alihdaya Publishing.

Regulation of Bank of Indonesia No.8/14/PBI/2006 on 05 October 2006 about changes of Regulation of Bank of Indonesia No.8/4/PBI/2006 on 30 January 2006.

Regulation of the State Minister for State-Owned Enterprises No. per - 01 /mbu/2011 about the Application of Good Corporate Governance on State-Owned Enterprises.

Sulistiyani, Ambar Teguh., \& Rosidah. (2003). Management of Human Resources. Yogyakarta: Graha IImu.

Tohari, Ahmad. (2002). Management of Human Resources. Bandung: Mandar Maju.

Wahyuni, Salamah., M.S. Idrus., Zain, Djumilah., \& Rahayu, Mintarti. (2011). Outsourcing Human Resources: Overview of Vendor and Employee Perspectives. Jurnal Aplikasi Manajemen, Vol. 9, (1).

Widjaja, Amin. (2008). Concept and Cases of Outsourcing. Jakarta: Harvarindo. 